\title{
ST 638
}

National Cancer Institute

\section{Source}

National Cancer Institute. ST 638. NCI Thesaurus. Code C1235.

A tyrosine kinase inhibitor that inhibits phospholipase $\mathrm{D}$ activity in human neutrophils at a site between the receptor and phospholipase. $(\mathrm{NCl})$ 